\title{
THE EFFECT OF RESIDENTIAL LOCATION ON THE PROBABILITY OF BLACK AND WHITE TEENAGERS HAVING A JOB
}

\author{
Keith R. Ihlanfeldt and David L. Sjoquist*
}

\section{Introduction}

One of the most debated issues regarding racial disparities in economic welfare is the affect of black population concentration within central cities on black employment. Beginning with Kain (1968), a number of economists and sociologists have argued that such concentration reduces black employment by limiting black workers' access to the growing number of job opportunities available in the suburbs. Among the reasons given for why the central city black resident has poor access to suburban jobs, two have received particular attention. First, the cost of commuting to a suburban job site may be prohibitively expensive for many blacks, since many cannot afford to own and operate an automobile and public transportation does not adequately serve the reverse commuter. Second, blacks may have limited knowledge of suburban job openings because friends and relatives, who frequently are relied upon in the search for a lower-skilled job, seldom work outside the central city.

In addition to the above "job access hypothesis," in recent years a new hypothesis has been advanced regarding the effect that black population concentration within central cities has on black employment. Wilson (1987) has argued that the outmigration of upwardly mobile blacks has left fewer and weaker institutional supports (churches, schools, etc.) and middle or working-class role models for the central city poor, which has caused negative changes in the individual labor force (and family) behaviors of those who have been left behind. Wilson has termed the influence of neighborhood characteristics on individual behav-

'Professors of Economics, and Senior Associates, Policy Research Program, Georgia State University. Research assistance was provided by Bob Eisenstadt, Laura Heuchan, and Joon Song. We wish to thank Richard Muth, Donald Williams, Christopher Winship, John Jackson, Louis Ederington, Paula Stephan, Jorge Martinez and two anonymous referees for helpful comments and discussions. This paper reports on a part of a larger research project that was conducted under a grant from the Economic Development Administration of the U.S. Department of Commerce. The statements, findings, conclusions and recommendations in this paper are those of the authors and do not necessarily reflect the views of the Economic Development Administration. ior as "concentration effects." While the discussion of these effects has focused on their importance within black central city neighborhoods, they obviously may operate within poor white city neighborhoods as well, because the suburbanization of higher income households has increased the incidence of both white and black poverty within central cities. ${ }^{1}$

Spatial differences in the proximity of lower-skill jobs and the importance of concentration effects imply that the individual's residential location within the metropolitan area may impinge on his economic welfare. A number of studies have investigated this issue by comparing the economic welfare (altematively measured by employment status, occupational status and earnings) of central city residents with otherwise similar suburban residents (Harrison, 1972; Bell, 1974; Vrooman and Greenfield, 1980; Reid, 1985; Price and Mills, 1985). These studies, which have yielded mixed results for both black and white workers, all suffer from a potentially serious shortcoming - the residential location of the individual worker was treated as exogenous. The evidence is overwhelming that the worker's economic status affects his choice of location. Hence, while a suburban location may increase the probability of having a job (by offering superior job access and an absence of concentration effects), it is also true that people with jobs are more likely to self-select a suburban residence. The failure to account for this simultaneity between residential location and economic welfare has likely biased the results obtained in earlier studies.

There are two approaches that might be taken to overcome the simultaneity problem, and thereby provide reliable estimates of the residential location effect on the probability of employment: (1) a system of equations could be estimated that treats both employment and residential location as endogenous variables, or (2) the analysis could be restricted to those individuals whose residential locations can legitimately be considered as exogenous. While the first approach is preferred, the data requirements exceed what is currently available. The purpose of this study, therefore, was to implement the second approach by analyzing the employment probabilities of teenagers, aged 16 to 19 , who were still living at home with their parents or guardians. Since it is unlikely that the employment status of these youth has much of an influence on where their parents choose to reside, simultaneity between the youth's 
job probability and his residential location should not be a problem.

There are two additional reasons for why we choose to focus our analysis on teenagers. First, racial differences in employment rates are larger for teenagers than for any other group. Currently, the employment rate for black teenagers in only about one-half as high as the employment rate for white teenagers. Recent research by Ellwood (1986) suggests that virtually none of this gap can be attributed to the residential location of black and white youth. However, his sample consisted of out-of-school youth aged 16 to 21, who lived both at home and on their own. For this group, simultaneity between residential location and job probability again may be a problem.

A final reason for studying teenagers is that they represent an interesting test group, since job access and concentration effects are likely to be stronger for them than adults. Regarding job access, teenagers may have greater difficulty commuting to distant jobs, since they are less likely to have an automobile available. Moreover, as documented by Holzer (1987), for both white and black youths, the most frequently used methods of job search are checking with friends and relatives and direct applications without referrals. The reliance on these informal methods of search suggests that the teenager's information on available jobopportunities may decay rapidly with distance from home. Concentration effects are expected to have a greater influence on youth than adults, since youth are directly affected by the erosion of school quality accompanying the outmigration of families of higher social economic status and the value systems of youth are most affected by the loss of positive role models from their neighborhoods.

The evidence presented here suggests that residential location has a strong impact on both white and black youth job probability. These results were obtained by estimating a multinomial logit model, which recognizes the joint endogeneity of employment and school enrollment, with data from the Chicago metropolitan area. Furthermore, according to our results, at a minimum, about a fifth of the black/white employment rate differential among Chicago's youth can be attributed to residential segregation.

\section{Data and Empirical Method}

The data employed to investigate the effect of intrametropolitan residential location on the teenager's probability of having a job came from the Public Use Sample of the 1980 Census of Population for the Chicago SMSA. There were two reasons for using Chicago as the basis for this research. First, the PUS provides a finer breakdown of locations for Chicago than for many other SMSA's. Second, Chicago, due to its large metropolitan population, provides larger sample sizes of blacks in the suburbs.

In addition to the central city of Chicago, the PUS identifies the six counties that constitute the suburban ring: Dupage, Kane, Lake, Will, McHenry, and that portion of Cook County lying outside the city of Chicago. This information enabled us to improve upon the simple central city/suburban dichotomy employed in prior studies to define intrametropolitan location.

Apart from locational effects, the probability of employment of a youth will depend upon his or her human capital or personal characteristics. These characteristics will affect the amount of search that the youth will engage in and will make the youth more or less desirable compared to competitors. Likewise, the characteristics of the family with which the youth resides may affect the probability of employment. Family members may exert an influence on the amount of search the youth engages in, either by example or because of the financial condition of the family. Family members may also be able to directly influence the probability that the youth is able to secure employment, for example, because a parent may have influence at work or special information about a job opportunity. Finally, much education takes place in the home so that youth who have well-educated parents may have advantages in finding and holding jobs over other youth with the same amount of formal schooling.

To measure the relative influence of residential location, individual characteristics, and family background on youth employment, we estimated a multinomial logit model. Multinomial logit was selected after preliminary estimations with simpler models suggested that the decision to attend school and the decision to work are jointly endogenous. ${ }^{2}$ Formally, the model's specification was as follows:

$$
\begin{aligned}
\ln \left(\mathrm{P}_{\mathrm{ji}} / \mathrm{P}_{4 \mathrm{i}}\right) & =\sum_{\mathbf{k}=1}^{\mathrm{m}} \mathrm{a}_{\mathrm{jk}} \mathrm{I}_{\mathrm{ki}}+\sum_{\mathrm{r}=1}^{\mathrm{t}} \mathrm{b}_{\mathrm{jr}} \mathrm{F}_{\mathrm{ri}} \\
& +\sum_{\mathrm{s}=1}^{\mathrm{w}} \mathrm{c}_{\mathrm{js}} \mathrm{L}_{\mathrm{si}}+\varepsilon_{\mathrm{ji}}
\end{aligned}
$$

where $j=1,2,3$, and $i$ indexes individuals. The $P_{j}$ are variables that indicate which enrollment-employment category the youth is in: $P_{1}$ takes on the value of one if the youth was enrolled and employed, and zero otherwise; $P_{2}$ is one if the youth was employed but not enrolled, and zero otherwise; $\mathrm{P}_{3}$ is one if the youth was enrolled and not employed, and zero otherwise; and $\mathrm{P}_{4}$ is one if the youth 
was neither employed nor enrolled. Employment and enrolled refer to the youth's status at the time of the interview. Regardless of the number of hours worked, if the youth indicated he had a job, he was considered employed.

The $I_{r}$ and $F_{r}$ are the characteristics of the youth and those of his (her) family, respectively. In selecting the specific $I_{f}$ and $F_{x}$ variables employed, we attempted to include as many of the variables as the data permitted that have been found to be important in prior studies of youth employment (e.g., Freeman, 1982; Ehrenberg and Marcus, 1982). In particular, no variable appears to be excluded that might vary systematically with the youth's residential location. As defined in Table 1, I variables were age, sex, years of education, health status, whether the high school diploma had been obtained, and marital status. The $F_{s}$ variables were family income net of the youth's earnings and the following characteristics of the household head:

Table 1

Independent Variable Definitions

\section{Personal Charactertistics}

\begin{tabular}{|c|c|}
\hline AGE & Age of Youth \\
\hline GRADE & Years of education completed \\
\hline SPOUSE & Spouse of youth present in household $($ Yes $=1)$ \\
\hline HEALTHY & $\begin{array}{l}\text { Youth has no mental or physical problems limiting the type of work } \\
(\text { Yes }=1)\end{array}$ \\
\hline MALE & Youth is a female (Yes $=1)$ \\
\hline MA & Youth is a high school graduate (Yes $=1)$ \\
\hline
\end{tabular}

Family Background

FHEAD Residence in one-parent, female-headed family (Yes = 1)

HEDUC Completed years of education of head of household

Other family income (reference category $=$ less than $\$ 10.000$ )

INC2 Annual family income net of youth's earnings greater than $\$ 10,000$ and less than $\$ 20,000(\mathrm{Yes}=1)$

INC3 Net family income between $\$ 20,000$ and $\$ 30,000(Y e s=1)$

INC4 Net family income between $\$ 30,000$ and $\$ 50,000(Y e s=1)$

INC5 Net family income greater than $\$ 50,000$ (Yes $=1$ )

Qccupation of household head (reference category = head without a job)

$\begin{array}{ll}\text { MAN } & \text { Manager or professional } \\ \text { TECH } & \text { Technical, sales, or administrative support } \\ \text { SERV } & \text { Service } \\ \text { CRAFT } & \text { Precision production, craft and repair } \\ \text { LAB } & \text { Operators, fabricators, and laborers }\end{array}$

$\underline{\text { Residential Location (reference category }=\text { central city of Chicago) }}$

\begin{tabular}{ll} 
COOK & Cook County - outside city of Chicago \\
DUPAGE & Dupage County \\
KANE & Kane County \\
LAKE & Lake County \\
McHENRY & McHenry County \\
WILL & Will County \\
\hline
\end{tabular}


sex, education level, occupational class, and employment status. The $\mathrm{L}_{\mathrm{a}}$ variables were dummy variables indicating in which suburban area (county) the youth resides, with the central city serving as the reference category.

We restricted our sample to all youth, 16-19 years of age, who were living at home during the survey week. The number of 16-19 year olds who do not live at home is small; only $0.6 \%$ of $16-17$ year olds and $8 \%$ of $18-19$ year olds live outside their parent's residence (Freeman, 1982).

Separate equations were estimated for white males and white females. For the white equations, an $\mathrm{L}_{8}$ variable was included for each of the six counties comprising the Chicago SMSA: Dupage, Kane, Lake, Will, McHenry, and that portion of Cook County lying outside the city of Chicago. Because the number of black youth living in the suburbs outside of Cook County was small, to obtain more efficient parameter estimates, males and females were combined into a single sample, and a dummy variable for sex was added. In addition, geographic areas were combined so thatonly three $\mathrm{L}_{\mathrm{a}}$ variables were included for blacks: the contiguous counties of Cook outside Chicago and Dupage, the contiguous counties of Kane, Lake, and McHenry, and Will County.

\section{Results of the Empirical Analysis}

All three of the estimated multinomial logit equations are significant, as reflected in the overall Chi-square statistics, at the one percent level of significance. The estimated logit coefficients indicate the effect of a unit change in an independent variable on the log of the ratio of the probability of being in one of the first three categories to the probability of being in the fourth category, i.e., not enrolled and not employed. ${ }^{3}$ As such, these coefficients are cumbersome to interpret, particularly if the interest is in the effect of an independent variable on the sum of two probabilities. A simpler method of presenting multinomial logit results is to compute the implied partial derivative of each probability with respect to a change in the independent variable at the mean values of the probabilities. These estimates, along with the associated standard errors, are presented in Tables 2, 3, and 4.

The partial derivatives of the probabilities with respect to the $\mathrm{I}_{\mathrm{r}}$ and $\mathrm{F}_{\mathrm{r}}$ variables were generally statistically significant and performed as expected. Therefore, in the interest of conserving space, these results are not discussed.

The partial derivatives of the probabilities with respect to the residential location variables indicate that where the youth resides has an important influence on the probability of having a job. This is true for all three groups of youth. To better study location effects, we used our logit results to compute $\mathrm{P}_{1}, \mathrm{P}_{2}, \mathrm{P}_{3}$, and $\mathrm{P}_{4}$ at each location, hold- ing the values of the personal and family background variables constant at their respective sample means. These probabilities are reported in Table 5.

To illustrate the proper interpretation of these numbers, consider the employment probability $\left(\mathrm{P}_{1}+\mathrm{P}_{2}\right)$ reported for white male teenagers living in the city of Chicago (column 4, row 1). This number, .440, is the probability that a white male living in the city has a job, assuming he has the same characteristics as the average white male in the total sample. The probability reported for white males living in suburban Cook County is .523, which indicates that a change in residential location from the city to Cook County would increase job probability by .083 , ceteris paribus. Also computed for each area were the probabilities of employment conditional on school enrollment status, i.e., $\left[P_{1} /\left(P_{1}+P_{3}\right)\right]$ and $\left[P_{2} /\left(P_{2}+P_{4}\right)\right]$ for youth in school and out of school, respectively. This was done because residential location may have a different effect on the job probability of youth in-and out-of-school. For example, out-of-school youth may be more willing and able to commute farther distances and therefore be less affected by an absence of nearby jobs.

Turning first to the results for white males, the unconditional or overall probability of employment $\left(\mathrm{P}_{1}+\right.$ $\mathrm{P}_{3}$ ) and the conditional probabilities of employment are all higher outside the central city. Differences in all three probabilities between the city and the suburban areas are statistically significant at the five percent level by a twotailed test, with the exceptions of the difference between McHenry county and the city for in-school youth and all three probability differences between Will County and the city. (Will County comprises only $8 \%$ of the total population of the suburban ring.) Among the suburban counties the overall job probability is highest in Dupage, where the probability of the average youth having a job is 143 higher than within the city of Chicago. The spatial pattern of employment differs between in-school and out-of-school youth, with the in-school job probabilities highest in Dupage (.569) and Cook (.512), and the out-of-school job probabilities highest in Kane (.766) and McHenry (.721). An explanation for these differences is that the latter two counties have the greatest number of manufacturing jobs per capita within the SMSA. ${ }^{4}$ These are jobs that would appeal more to out-of-school in comparison to in-school youth. Differences in conditional job probabilities between the city and the suburban areas were in some cases larger for in-school youth (Cook, Dupage), but in other cases these differences were larger for out-of-school youth (Kane, Lake, McHenry).

Spatial differences in school enrollment probabilities $\left(P_{1}+P_{3}\right)$ were in all cases small. Dupage and Cook had slightly higher probabilities than the city, while the other 


\section{Table 2}

Implied Partial Derivatives of the Probability of

Each Enrollment, Employment Category: White Male Youth

(standard errors)

\begin{tabular}{|c|c|c|c|c|}
\hline & $\mathrm{P}_{1}$ & $\mathrm{P}_{2}$ & $\mathrm{P}_{3}$ & $\mathbf{P}_{4}$ \\
\hline \multicolumn{5}{|c|}{ Residential Location } \\
\hline \multirow[t]{2}{*}{ COOK } & $.080 *$ & .002 & $-.056^{*}$ & $-.022 *$ \\
\hline & .015 & .005 & .016 & .008 \\
\hline \multirow[t]{2}{*}{ DUPAGE } & $.121 *$ & $.018^{*}$ & $-.104 *$ & $-.035^{*}$ \\
\hline & .070 & .006 & .021 & .012 \\
\hline \multirow[t]{2}{*}{ KANE } & $.051 * *$ & $.081^{*}$ & $-.087^{*}$ & $-.045^{*}$ \\
\hline & .028 & .009 & .029 & .017 \\
\hline \multirow[t]{2}{*}{ LAKE } & $.047 *$ & $.040 *$ & $-.060 *$ & $-.027 * *$ \\
\hline & .024 & .008 & .025 & .014 \\
\hline \multirow[t]{2}{*}{ McHENRY } & .039 & $.064^{*}$ & $-.068 * *$ & -.035 \\
\hline & .036 & .012 & .037 & .022 \\
\hline \multirow[t]{2}{*}{ WILL } & .007 & $.038 *$ & $-.057 *$ & .011 \\
\hline & .027 & .009 & .028 & .12 \\
\hline \multicolumn{5}{|c|}{ Personal Characteristics } \\
\hline \multirow[t]{2}{*}{ AGE } & $-.085^{*}$ & $.170^{*}$ & $-.136^{*}$ & $.050 *$ \\
\hline & .008 & .003 & .008 & .004 \\
\hline \multirow[t]{2}{*}{ GRADE } & $.102^{*}$ & $-.062 *$ & -.008 & $-.031 *$ \\
\hline & .007 & .002 & .006 & .002 \\
\hline \multirow{2}{*}{ SPOUSE } & -.114 & $.122^{*}$ & -.120 & $.112^{*}$ \\
\hline & .084 & .028 & .087 & .023 \\
\hline \multirow[t]{2}{*}{ HEALTHY } & .058 & $.099 *$ & $-.107 *$ & $-.050 *$ \\
\hline & .043 & .013 & .041 & .015 \\
\hline \multirow[t]{2}{*}{ DIPLOMA } & $-.186^{*}$ & $.289 *$ & $-.182 *$ & $.079 *$ \\
\hline & .018 & .006 & .020 & .008 \\
\hline \multicolumn{5}{|c|}{ Family Background } \\
\hline \multirow[t]{2}{*}{ FHEAD } & .013 & $.045^{*}$ & $-.064 *$ & .005 \\
\hline & .020 & .006 & .021 & .009 \\
\hline \multirow[t]{2}{*}{ HEDUC } & .002 & $-.014^{*}$ & $.015^{*}$ & -.002 \\
\hline & .010 & .003 & .006 & .002 \\
\hline \multicolumn{5}{|c|}{ Other Family Income } \\
\hline \multirow[t]{2}{*}{ INC2 } & $.071 *$ & $-.028^{*}$ & -.019 & $-.024 *$ \\
\hline & .029 & .009 & .029 & .011 \\
\hline \multirow[t]{2}{*}{ INC3 } & $.114^{*}$ & $-.053^{*}$ & -.006 & $-.054^{*}$ \\
\hline & .028 & .009 & .028 & .011 \\
\hline \multirow[t]{2}{*}{ INC4 } & $.124^{*}$ & $-.056^{*}$ & -.002 & $-.006 *$ \\
\hline & .028 & .009 & .028 & .012 \\
\hline \multirow[t]{2}{*}{ INC5 } & $.075^{*}$ & $-.062 *$ & $.055^{* *}$ & $-.068 *$ \\
\hline & .031 & .010 & .031 & .014 \\
\hline \multicolumn{5}{|c|}{ Occupation of Head } \\
\hline MAN & $.068^{*}$ & .008 & -.020 & $-.056^{*}$ \\
\hline & .025 & .008 & .026 & .013 \\
\hline TECH & $.058 *$ & $.023^{*}$ & $-.043 * *$ & $-.038 *$ \\
\hline & .024 & .008 & .025 & .011 \\
\hline SERV & .033 & $.063 *$ & $-.071 *$ & $-.024 * *$ \\
\hline & .030 & .010 & .031 & .013 \\
\hline CRAFT & $.144^{*}$ & $.079 *$ & $-.082^{*}$ & $-.107 *$ \\
\hline & .025 & .008 & .025 & .011 \\
\hline LAB & -.002 & $.076^{*}$ & $-.065^{*}$ & -.008 \\
\hline & .025 & .008 & .026 & .011 \\
\hline
\end{tabular}

*Coefficient significant at five percent level, two-tailed test.

**Coefficient significant at ten percent level, two-tailed test.

$P_{1}=$ enrolled and employed; $P_{2}=$ employed, not enrolled;

$P_{3}=$ enrolled, not employed; $P_{4}=$ not enrolled, not employed. 
The Effect of Residential Location on the Probability

Table 3

Implied Partial Derivatives of the Probability of Each Enrollment, Employment Category: White Female Youth

(standard errors)

\begin{tabular}{|c|c|c|c|c|}
\hline & $\mathrm{P}_{1}$ & $\mathbf{P}_{2}$ & $\mathbf{P}_{3}$ & $\mathbf{P}_{4}$ \\
\hline \multicolumn{5}{|l|}{ Residential Location } \\
\hline \multirow[t]{2}{*}{ COOK } & $.069 *$ & $.031^{*}$ & -.091 & -.010 \\
\hline & .016 & .005 & .016 & .008 \\
\hline \multirow{2}{*}{ DUPAGE } & $.090 *$ & $.046^{*}$ & $-.128 *$ & -.008 \\
\hline & .021 & .007 & .022 & .012 \\
\hline \multirow[t]{2}{*}{ KANE } & .045 & $.063^{*}$ & $-.120 *$ & -.012 \\
\hline & .030 & .010 & .032 & .015 \\
\hline \multirow{2}{*}{ LAKE } & .012 & $.104^{*}$ & $-.132 *$ & -.016 \\
\hline & .026 & .008 & .026 & .013 \\
\hline \multirow{2}{*}{ McHENRY } & .049 & $.053^{*}$ & $-.080^{*}$ & -.022 \\
\hline & .037 & .012 & .038 & .024 \\
\hline \multirow[t]{2}{*}{ WILL } & -.027 & $.039 *$ & -.033 & .020 \\
\hline & .029 & .009 & .028 & .013 \\
\hline \multicolumn{5}{|l|}{ Personal Characteristics } \\
\hline \multirow[t]{2}{*}{ AGE } & $-.067 *$ & $.164^{*}$ & $-.134^{*}$ & $.038^{*}$ \\
\hline & .009 & .003 & .009 & .004 \\
\hline \multirow[t]{2}{*}{ GRADE } & $.087^{*}$ & $-.053^{*}$ & -.0008 & $-.033^{*}$ \\
\hline & .008 & .003 & .007 & .003 \\
\hline \multirow[t]{2}{*}{ SPOUSE } & $-.242 *$ & $.207^{*}$ & -.128 & $.163^{*}$ \\
\hline & .084 & .028 & .080 & .017 \\
\hline \multirow{2}{*}{ HEALTHY } & .070 & $.138^{*}$ & -.1698 & $-.039 *$ \\
\hline & .051 & .016 & .047 & .018 \\
\hline \multirow[t]{2}{*}{ DIPLOMA } & $-.226^{*}$ & .3458 & $-.208^{*}$ & $.087 *$ \\
\hline & .019 & .007 & .021 & .009 \\
\hline \multicolumn{5}{|l|}{ Family Background } \\
\hline \multirow[t]{2}{*}{ FHEAD } & $.043^{*}$ & .005 & $.058 *$ & .009 \\
\hline & .021 & .007 & .021 & .009 \\
\hline \multirow[t]{2}{*}{ HEDUC } & $.007^{*}$ & $-.014^{*}$ & $.012^{*}$ & $-.005 *$ \\
\hline & .002 & .0007 & .002 & .001 \\
\hline \multicolumn{5}{|l|}{ Other Family Income } \\
\hline \multirow[t]{2}{*}{ INC2 } & .042 & $-.028 *$ & -.002 & -.012 \\
\hline & .031 & .009 & .029 & .011 \\
\hline \multirow[t]{2}{*}{ INC3 } & $.079^{*}$ & $-.024^{*}$ & -.024 & $-.031^{*}$ \\
\hline & .030 & .009 & .029 & .012 \\
\hline \multirow[t]{2}{*}{ INC4 } & $.141^{*}$ & $-.058^{*}$ & -.028 & -.055 \\
\hline & .030 & .009 & .029 & .013 \\
\hline \multirow[t]{2}{*}{ INC5 } & $.082 *$ & $-.047 *$ & .029 & $-.064^{*}$ \\
\hline & .033 & .010 & .032 & .016 \\
\hline \multicolumn{5}{|l|}{ Occupation of Head } \\
\hline$\overline{\mathrm{MAN}}$ & $.088^{*}$ & $-.050^{*}$ & -.0003 & $-.038^{*}$ \\
\hline & .027 & .009 & .027 & .013 \\
\hline TECH & $.071^{*}$ & .007 & -.035 & $-.042 *$ \\
\hline & .027 & .009 & .026 & .012 \\
\hline SERV & $.096^{*}$ & .016 & -.042 & $-.037 *$ \\
\hline & .031 & .010 & .031 & .014 \\
\hline CRAFT & $.065^{*}$ & .014 & $-.062^{*}$ & -.017 \\
\hline & .027 & .009 & .027 & .011 \\
\hline LAB & .032 & $.024^{*}$ & $-.045 * *$ & -.011 \\
\hline & .027 & .009 & .027 & .011 \\
\hline
\end{tabular}

*Coefficient significant at five percent level, two-tailed test.

**Coefficient significant at ten percent level, two-tailed test.

$P_{1}=$ enrolled and employed; $P_{2}=$ employed, not enrolled;

P3 = enrolled, not employed; P4 = not enrolled, not employed. 
Table 4

Implied Partial Derivatives of the Probability of Each Enrollment, Employment Category: Black Youth

(standard errors)

\begin{tabular}{|c|c|c|c|c|}
\hline & $\overline{P_{1}}$ & $\overline{P_{2}}$ & $\mathrm{P}_{3}$ & $\mathrm{P}_{4}$ \\
\hline \multicolumn{5}{|l|}{ Residential Location } \\
\hline \multirow{2}{*}{ COOK, DUPAGE } & $.068 *$ & $.016 * *$ & $-.064^{*}$ & -.020 \\
\hline & .012 & .009 & .025 & .022 \\
\hline \multirow{2}{*}{ KANE, LAKE, McHENRY } & $.106^{*}$ & $.065^{*}$ & $-.156^{*}$ & -.015 \\
\hline & .022 & .015 & .049 & .043 \\
\hline \multirow[t]{2}{*}{ WILL } & .030 & $.035^{* *}$ & $-.126^{*}$ & .061 \\
\hline & .029 & .018 & .052 & .041 \\
\hline \multicolumn{5}{|l|}{ Personal Characteristics } \\
\hline \multirow[t]{2}{*}{ AGE } & $-.015^{*}$ & $.068 *$ & $-.199 *$ & $.145^{*}$ \\
\hline & .005 & .004 & .009 & .007 \\
\hline \multirow[t]{2}{*}{ GRADE } & $.042 *$ & $-.011^{*}$ & $.030 *$ & $-.062 *$ \\
\hline & .005 & .002 & .007 & .005 \\
\hline \multirow[t]{2}{*}{ SPOUSE } & .030 & $.043^{*}$ & $-.178 *$ & $.104 *$ \\
\hline & .036 & .020 & .062 & .044 \\
\hline \multirow[t]{2}{*}{ HEALTHY } & .031 & .028 & -.061 & .002 \\
\hline & .031 & .018 & .044 & .033 \\
\hline \multirow[t]{2}{*}{ DIPLOMA } & $-.042^{*}$ & $.098^{*}$ & $-.232 *$ & $.174 *$ \\
\hline & .013 & .007 & .023 & .017 \\
\hline \multirow[t]{2}{*}{ FEMALE } & .006 & $.028 *$ & $-.025 * *$ & -.009 \\
\hline & .009 & .006 & .015 & .012 \\
\hline \multicolumn{5}{|l|}{ Family Background } \\
\hline \multirow[t]{2}{*}{ FHEAD } & -.009 & -.011 & $-.046^{*}$ & $.067 *$ \\
\hline & .011 & .007 & .018 & .015 \\
\hline \multirow{2}{*}{ HEDUC } & .002 & -.001 & .005 & $-.007 *$ \\
\hline & .002 & .001 & .003 & .002 \\
\hline \multicolumn{5}{|l|}{ Other Family Income } \\
\hline \multirow[t]{2}{*}{ INC2 } & $.037 *$ & .012 & $-.036 * *$ & -.013 \\
\hline & .013 & .008 & .020 & .016 \\
\hline \multirow{2}{*}{ INC3 } & $.034^{*}$ & .009 & -.013 & -.030 \\
\hline & .015 & .009 & .025 & .020 \\
\hline \multirow[t]{2}{*}{ INC4 } & .013 & .016 & .005 & -.034 \\
\hline & .016 & .010 & .027 & .022 \\
\hline \multirow{2}{*}{ INC5 } & $.065^{*}$ & -.0002 & -.046 & -.019 \\
\hline & .023 & .017 & .046 & .040 \\
\hline \multicolumn{5}{|l|}{ Occupation of Head } \\
\hline \multirow[t]{2}{*}{ MAN } & $.044^{*}$ & $-.038 *$ & $.090 *$ & $-.096 *$ \\
\hline & .019 & .014 & .035 & .031 \\
\hline \multirow[t]{2}{*}{ TECH } & $.049 *$ & -.009 & .025 & $.065^{*}$ \\
\hline & .014 & .009 & .025 & .021 \\
\hline \multirow[t]{2}{*}{ SERV } & $.049 *$ & $.017 * *$ & $-.043 * *$ & -.023 \\
\hline & .015 & .009 & .025 & .020 \\
\hline \multirow[t]{2}{*}{ CRAFT } & .021 & .002 & .021 & $-.045 * *$ \\
\hline & .019 & .018 & .032 & .027 \\
\hline LAB & $.026 * *$ & .003 & -.004 & -.026 \\
\hline & .014 & .009 & .023 & .018 \\
\hline
\end{tabular}

*Coefficient significant at five percent level, two-tailed test.

**Coefficient significant at ten percent level, two-tailed test.

$P_{1}=$ enrolled and employed; $P_{2}=$ employed, not enrolled;

P3 = enrolled, not employed; P4 = not enrolled, not employed. 
Table 5

Probabilities of Each Area Calculated at the

Mean Values of the Independent Variables for Each Sample

\begin{tabular}{lcccccccc}
\hline \hline & $P_{1}$ & $P_{2}$ & $P_{3}$ & $P_{4}$ & $P_{1}+P_{2}$ & $P_{1}+P_{3}$ & $\frac{P_{1}}{P_{1}+P_{3}}$ & $\frac{P_{1}}{P_{2}+P_{4}}$ \\
\hline White Males & & & & & & & & \\
Chicago & .353 & .087 & .482 & .078 & .440 & .835 & .423 & .526 \\
Cook & .438 & .085 & .418 & .058 & .523 & .856 & .512 & .595 \\
Dupage & .487 & .096 & .368 & .048 & .583 & .855 & .569 & .665 \\
Kane & .415 & .144 & .397 & .044 & .559 & .812 & .511 & .766 \\
Lake & .411 & .112 & .422 & .055 & .523 & .833 & .493 & .671 \\
Will & .368 & .111 & .430 & .092 & .479 & .798 & .461 & .547 \\
McHenry & .405 & .130 & .415 & .050 & .535 & .820 & .494 & .721 \\
White Females & & & & & & & & \\
Chicago & .384 & .078 & .484 & .054 & .462 & .868 & .442 & .590 \\
Cook & .471 & .094 & .387 & .047 & .565 & .858 & .548 & .666 \\
Dupage & .498 & .103 & .350 & .049 & .601 & .848 & .587 & .675 \\
Kane & .451 & .114 & .367 & .067 & .565 & .818 & .552 & .628 \\
Lake & .422 & .148 & .358 & .072 & .570 & .780 & .541 & .671 \\
Will & .367 & .098 & .460 & .075 & .465 & .827 & .444 & .569 \\
McHenry & .453 & .107 & .401 & .039 & .560 & .854 & .530 & .730 \\
Blacks & & & & & & & & \\
Chicago & .110 & .041 & .661 & .188 & .151 & .771 & .143 & .181 \\
Cook, Dupage & .193 & .051 & .587 & .169 & .244 & .780 & .248 & .232 \\
Kane, Lake, McHenry & .255 & .095 & .484 & .167 & .350 & .739 & .345 & .362 \\
Will & .143 & .067 & .538 & .252 & .210 & .681 & .210 & .210 \\
\hline \hline
\end{tabular}

$P_{1}=$ enrolled and employed; $P_{2}=$ employed and enrolled; $P_{3}=$ enrolled, not employed; $P_{4}=$ not enrolled, not employed; $P_{1}+P_{2}=$ probability of employment; $P_{1}+P_{3}=$ probability of school enrollment; $P_{1} /\left(P_{1}+P_{3}\right)=$ conditional probability of employment, youth in school; $\mathrm{P}_{1} /\left(\mathrm{P}_{2}+\mathrm{P}_{4}\right)=$ conditional probability of employment, youth out-of school.

suburban areas had somewhat lower probabilities than the city. However, the differences are not statistically significant.

The results for white females parallel those obtained for white males, with unconditional and conditional job probabilities significantly higher outside the central city, except in the case of Will County. All three probabilities were highest in Dupage County. In contrast to the results for males, city-suburban differences in conditional probabilities were more frequently smaller for out-of-school in comparison to in-school youth, with the only exception being the differences for McHenry County. Also contrasting with white males, and somewhat of a surprise, was the finding that white female school enrollment probabilities were uniformly lower outside the central city, but once again these differences were generally small in magnitude and not statistically significant.
A less disaggregated spatial comparison of probabilities is possible for black teenagers, since fewer location variables were included in the estimated logit equation. Nevertheless, the probabilities estimated for blacks suggest the same spatial patterns as those found for whites: (1) all three employment probabilities (i.e., unconditional, in-school, out-of-school) are higher for black teenagers in the suburbs in comparison to the central city, with the magnitudes of the city-suburban differences on the whole as large as those observed for whites and statistically significant, except those between the city and Will County; (2) as for white females, spatial differences in conditional probabilities are smaller for out-of-school in comparison to in-school youth; and (3) school enrollment probabilities are similar among areas, except for Will County where the enrollment rate was approximately nine percent lower than within the central city. 
The similar spatial differences in employment probabilities observed for white and black youth are relevant to the hypothesis that blacks encounter greater hiring discrimination outside the central city, allegedly because white consumers are prejudiced against black workers (Kain, 1968; Offner and Saks, 1971). While our model is not designed to uncover spatial variation in the degree of labor market discrimination, our findings do suggest that if discrimination is more severe in the suburbs, its effect on black job probability is dominated by the job availability and absence of concentration effects that are found in the suburbs.

\section{The Role of Location in Explaining the Racial Difference in Youth Employment Rates}

Since black youth are heavily concentrated within the central city, an implication of our finding that, ceteris paribus, job probabilities are higher in suburbia, is that a portion of the racial gap in youth employment rates can be attributed to housing segregation. Estimates of the magnitude of the size of this portion were obtained by conducting pseudo-experiments. Essentially, the experiments involved desegregating the sample by reallocating youth among jurisdictions and calculating the hypothetical difference in employment rates between white and black youth. The sample was desegregated using three alternative techniques (henceforth referred to as Techniques 1, 2, and 3). Technique 1 randomly allocates white males (females) to the six counties and the city in the same proportion as the actual distribution of black males (females). Technique 2 randomly allocates black males (females) to the counties and city in the same proportion as the actual distribution of white males (females). Technique 3 allocates white and black males (females) across jurisdictions in proportions equal to the actual distribution of all males (females), regardless of race. Results may differ between these three techniques, since Technique 1 makes use of the logit regression equations for whites, Technique 2 makes use of the logit equations for blacks, and Technique 3 uses both sets of equations.

Estimation of the percentage of the racial difference in employment rates attributable to location (i.e., housing segregation) is described for male youth using Technique 1:

1. White males were randomly allocated to the six counties and the city in the same proportion as the actual distribution of black males.

2. Using the logit regression equations for the white males, the four probabilities, $\mathrm{P}_{1}, \ldots, \mathrm{P}_{4}$, were calculated for each white male taking into account the jurisdiction to which each white male had been allocated.
3. Given the predicted probabilities for each white male, the mean probabilities were calculated. These probabilities serve as the predicted frequencies for the four employment-school enrollment categories for the entire white male sample.

4. Using the actual frequencies for white males and black males, the actual difference in employment rates between black and white males was determined. Using the predicted frequencies for white males and the actual frequencies for black males, the predicted or hypothetical difference in employment rates was calculated. The change in the difference in employment rates was calculated and expressed as a percentage of the actual difference.

Results are reported in Table 6, which also contains the actual difference in employment rates. Differences in youth employment rates attributable to housing segregation are very similar across the three desegregation techniques, which adds robustness to our findings. Since the effects of a policy of the suburban dispersal of the black population are of considerable interest, we focus on the results obtained with Technique 2 . For male youth, $19.7 \%$ of the overall difference in the employment rate between whites and blacks is explained by location, while for females location explains $16.7 \%$. Location explains a larger percentage of the difference in employment rates between youth who are in-school than for those out-ofschool. $22.3 \%$ and $20.4 \%$ of the black/white gap is attributable to location for in-school males and females, respectively. The corresponding percentages for out-of-school youth were $13.1 \%$ and $9.4 \%$. Location is less important in the case of out-of-school youth because these youth are less segregated than in-school youth, and in the case of females, spatial differences in job probabilities were relatively small for youth out-of-school. ${ }^{5}$

The numbers in Table 6 suggest that housing segregation plays a substantial role in explaining the difference in employment rates between white and black youth living in the Chicago metropolitan area. It is important to note that our estimates should be interpreted as lower bounds. In ourcalculations, concentration and job access effects are assumed to be the same for blacks and whites living within the central city. However, the city of Chicago is quite segregated with whites living predominantly in the northwest and blacks predominantly in the south. Concentration effects are expected to be more important on the south side than on the north side of the city. In addition, Ellwood (1986) presents evidence which suggests that job access is worse on the city's south side. Hence, if the data had permitted separate job probability estimates for the north and south sides of the city of Chicago, we expect that more of the difference in employment rates could have been 
The Effect of Residential Location on the Probability

of Black and White Teenagers Having a Job

Table 6

Estimates of the Percentage of the Racial Difference in Youth Employment Rates Attributable to Housing Segregation

\begin{tabular}{llllllll}
\hline \hline & \multicolumn{3}{c}{ Males } & & \multicolumn{3}{c}{ Females } \\
\cline { 2 - 4 } & $\begin{array}{c}\text { Full } \\
\text { Sample }\end{array}$ & $\begin{array}{c}\text { In } \\
\text { School }\end{array}$ & $\begin{array}{c}\text { Out of } \\
\text { School }\end{array}$ & & $\begin{array}{c}\text { Full } \\
\text { Sample }\end{array}$ & $\begin{array}{c}\text { In } \\
\text { School }\end{array}$ & $\begin{array}{c}\text { Out of } \\
\text { School }\end{array}$ \\
\hline $\begin{array}{l}\text { Actual Racial Difference } \\
\text { in Youth Employment Rates }\end{array}$ & $33.63 \%$ & $31.99 \%$ & $40.97 \%$ & & $37.64 \%$ & $34.16 \%$ & $49.22 \%$ \\
$\begin{array}{l}\text { \% of Difference Explained } \\
\begin{array}{l}\text { Technique (1) } \\
\text { Technique (2) }\end{array}\end{array}$ & $16.24 \%$ & $18.47 \%$ & $10.98 \%$ & & $14.88 \%$ & $18.15 \%$ & $5.12 \%$ \\
Technique (3) & 19.74 & 22.29 & 13.08 & & 16.74 & 20.35 & 9.43 \\
\hline \hline
\end{tabular}

The difference equals the white male (female) employment rate less the black male (female) employment rate, both expressed as percentages.

Technique 1 allocates whites among areas in the same proportion as the actual distribution of blacks. Technique 2 allocates blacks in the same proportion as the actual distribution of whites. Technique 3 allocates whites and blacks across areas in proportions equal to the actual distributions of the teenager population.

explained by housing segregation. How much more, of course, is a question for future research using data with more detailed spatial identification. Our best guess, however, is that the percentages in Table 6 would increase by nontrivial amounts.

\section{Conclusion}

The simultaneity between economic welfare and residential location may have biased the results of prior studies that have investigated the effect of intrametropolitan location on employment and eamings. This study has avoided this problem by focusing the analysis on a group whose residential locations can legitimately be treated as exogenous - teenagers living at home. Our findings suggest that residential location has a strong impact on the job probability of both black and white teenagers living within the Chicago SMSA and that a nontrivial portion of the racial difference in teenager employment rates can be attributed to residential segregation. Hence, the high level of black youth joblessness is partly a problem of location, and not solely one of race.

The issue of exactly why residential location matters to job probability was left unresolved by this study. The findings were, however, consistent with Kain's job access hypothesis and Wilson's concentration effects hypothesis. Future research should be directed at determining the relative importance of these two hypotheses (and perhaps others) as explanations for the effect of residential location on employment.
Notes

'Within central cities, the white poverty rate increased from 9.4 percent in 1974 to 14.9 percent in 1985 . Over the same time period, the black poverty rate increased from 28.3 percent to 32.1 percent (U.S. Bureau of the Census, Current Population Reports, series P-60).

${ }^{2}$ Multinomial logit analysis estimates reduced form equations representing statistical association between different combinations of choices and a matrix of independent variables that affect the choices. An attempt was made to estimate the structural equations underlying the employment and enrollment decisions by employing a two-step maximum likelihood probit technique (Maddala, 1986). Unfortunately, the system could not be adequately identified for reliable parameter estimation.

The actual logit equations are not reported but are available from the authors upon request.

${ }^{4}$ See Ward, 1985, Table 10.

'We employed separate equations for white males and females but a single equation for blacks with a sex dummy variable, for reasons given in Section II. Since there may be some questions about the implications of this approach, we also estimated a single equation for whites with a sex dummy variable. The results are consistent with those in Table 2. As expected, however, the fit of the single equation model is inferior to the two equation models, as measured by the log likelihood ratio.

${ }^{6}$ Reproducing the results of Table 2 using the single equation model for whites results in slightly smaller predicted changes in the employment gap using desegregation Technique 1. Thus if we had been able to use the superior two-equation model for 
blacks, we expect that the explained difference would be slightly larger than those reported in Table 2.

\section{References}

Bell, D. "Residential Location, Economic Performance, and Public Employment." In G. Von Furstenberg, A. Horowitz, andB. Harrison (eds.). Patterns of Racial Discrimination, Vol. 1, Heath, Lexington, 1974.

Ehrenberg, Ronald G. and Alan H. Marcus. "Minimum Wages and Teenagers' Enrollment-Employment Outcomes: A Multinomial Logit Model." Joumal of Human Resources, Winter XVII:39-58, 1982.

Ellwood, David T. "The Spatial Mismatch Hypothesis: Are There Teenage Jobs Missing in the Ghetto?" In R. B. Freeman and H. J. Holzer (eds.). The Black Youth Employment Crisis, Chicago: The University of Chicago Press, pp. 147187, 1986.

Freeman, Richard B. "Economic Determinants of Geographic and Individual Variation in the Labor Market Position of Young Persons." In R. B. Freeman and D. A. Wise (eds.). The Youth Labor Market Problem: Its Nature, Causes, and Consequences, Chicago: The University of Chicago Press, pp. 115-148.

Harrison, B. "The Intrametropolitan Distribution of Minority Economic Welfare." Journal of Regional Science, April 12:23-43, 1972.

Holzer, Harry J. "Informal Job Search and Black Youth Unem- ployment." American Economic Review, 77(3), June:446$52,1987$.

Kain, J. F. "Housing Segregation, Negro Employment, and Metropolitan Decentralization." Quarterly Joumal of Economics, 82:175-197, 1968.

Maddala, G. S. Limited Dependent and Qualitative Variables in Econometrics, Cambridge: Cambridge University Press, 1986.

Offner, P. and D. H. Saks. "A Note on John Kain's Housing Segregation, Negro Employment and Metropolitan Decentralization." Quarterly Journal of Economics, 85:145-160, 1971.

Price, Richard and Edwin Mills. "Race and Resident in Earnings Determination." Journal of Urban Economics, Vol. 17:1-18, 1985.

Reid, Clifford E. "The Effect of Residential Location on the Wages of Black Women and White Women." Journal of Urban Economics, November:350-63, 1985.

Vrooman, J. and S. Greenfield. "Are Blacks Making It in the Suburbs? Some New Evidence on Intra-Metropolitan Spatial Segmentation." Journal of Urban Economics 7:155-167, 1980.

Ward, Sally A. Where Workers Work in the Chicago Standard Metropolitan Statistical Area, Chicago: Illinois Department of Employment Security, 1985.

Wilson, William Julius. The Truly Disadvantaged: The Inner City, the Underclass, and Public Policy, Chicago: University of Chicago Press, 1987 